International Journal of Child, Youth and Family Studies (2020) 11(2): 25-39

DOI: $10.18357 /$ ijcyfs112202019517

\title{
RE-IMAGINING CHILD AND YOUTH CARE PRACTICE WITH AFRICAN CANADIAN YOUTH
}

\section{Beverly-Jean Daniel and Johanne Jean-Pierre}

\begin{abstract}
This article is based on a plenary held during the Child \& Youth Care in Action VI Conference: Moving Through Trails and Trials Toward Community Wellness, held in Victoria, British Columbia in April 2019. It explores how we can re-imagine child and youth care practice with African Canadian youth. This emerging paradigm aligns with child and youth care politicized praxis as well as trauma-informed and strengths-based approaches in the field's literature. We highlight the importance of mobilizing critical and transformative theoretical frameworks along with an Africentric worldview to substantially support youth of African descent with a strengths-based approach. Moreover, the protective role of Black-affirming spaces is developed and articulated.
\end{abstract}

Keywords: child and youth care (CYC), youth work, Black-affirming space, African Canadian, youth

Beverly-Jean Daniel PhD (the corresponding author) is an Assistant Professor in the School of Child and Youth Care at Ryerson University, 350 Victoria St., Toronto, ON M5B 2K3. Email: bdaniel@ryerson.ca

Johanne Jean-Pierre $\mathrm{PhD}$ is an Assistant Professor in the School of Child and Youth Care at Ryerson University, 350 Victoria St., Toronto, ON M5B 2K3. Email: jjeanpierre@,ryerson.ca 
International Journal of Child, Youth and Family Studies (2020) 11(2): 25-39

\section{Johanne Jean-Pierre}

Child and youth care professionals provide primary supportive care and engage in relational practice, life-skills teaching, counselling on the go, discipline, and dialogue with children and youth across various human services sectors (Krueger, 2007; Maier, 1991; Mann-Feder \& Litner, 2004). The literature in the field emphasizes frontline work, microsystemic dynamics, and the centrality of relationship building (Bellefeuille et al., 2008; de Finney et al., 2012; VanderVen, 1993). Yet children and youth are affected by exosystemic and macrosystemic factors that constrain their development, interests, and aspirations. In fact, whether acknowledged or not, structural barriers and historically entrenched inequalities impact one's frames of reference and the decision-making processes one employs. Everyday frontline interactions, and therapeutic and recreational interventions, are embedded in international, national, historical, social, political, and economic inequalities and inequities (de Finney et al., 2012); thus, decisions concerning these actions cannot be solely based on practitioners' intentions, empathy, formal training, or years of experience. For instance, Black Canadian youth, also called African Canadian youth, are disproportionately represented in the child welfare system (Ontario Human Rights Commission, 2018; Pon et al., 2011; United Nations General Assembly, 2017) and experience documented challenges in the areas of schooling, post-secondary education, criminal justice, and employment (Bernard \& Smith, 2018; Briggs, 2018; Bundy, 2019; Collins \& Magnan, 2018; Creese, 2010; James, 2012, 2019; Kanu, 2008; Lafortune, 2019; Robson et al., 2018; Schroeter \& James, 2015; Thésée \& Carr, 2014; Usman, 2012; Wortley \& Owusu-Bempah, 2011). Perhaps we should decentre our attention from individual life trajectories and risk factors to examine closely the systemic and institutional factors that affect Black youth. Hence, we open the possibility of dismantling the structural barriers that stand in the way of African Canadian youth's development, well-being, and success.

The plenary session entitled "Re-imagining Child and Youth Care Practice with African Canadian Youth" at the Child \& Youth Care in Action VI Conference aimed to introduce child and youth care professionals to anti-racist and Africentric child and youth care praxis. Child and youth care professionals can play a crucial constructive role alongside African Canadian youth in enacting and promoting racial equity, social change, positive development, excellence, and wellbeing among Black youth from various national, ethnic, cultural, linguistic, and religious backgrounds. In doing so, attendees were invited to be receptive to critical theories and paradigms regarding ethical child and youth care practice. The plenary speakers contended that:

1) An Africentric worldview and critical race theory consolidate strengths-based approaches.

2) Black-affirming spaces are empowering and beneficial for African Canadian youth. 
International Journal of Child, Youth and Family Studies (2020) 11(2): 25-39

\section{Critical Ethical and Transformative Practice with Youth of African Descent}

Conference attendees were invited to reflect on their assumptions about their work, to be open to learning, and to scrutinize their defence mechanisms. Sometimes, a child and youth care practitioner might dismiss this plenary's content because they consider that they already have good intentions, empathy, and relational practice skills. Others may estimate that, professionally, they are satisfied with the work that is now being accomplished with African Canadian children and youth. In some instances, practitioners with years of experience may believe that because they focus on therapeutic approaches and not advocacy, anti-oppressive theories and an Africentric paradigm are inconsequential. Others might minimize critical theories because they have personal and intimate relationships with family members and friends of African descent. Unbeknownst to the practitioners, who often have a minimal understanding of the historical legacy and contemporary expressions of anti-Black racism, these attitudes and beliefs constitute different forms of defence mechanism that perpetuate exclusionary and racist practices. In fact, child and youth care professionals can fail to recognize that a racist incident has occurred, can seem bewildered when someone names racism, and can prefer to leave the issue unaddressed and move on. This indifference in and of itself condones and reinforces racism; inaction after a racist incident takes place or is reported deeply affects Black youth (James et al., 2010).

One can be tempted to believe that the willingness to engage in a dialogue and listen to individual Black youth's personal stories with great empathy is equivalent to a commitment to equity. Yet the former can constitute a type of voyeurism or a consumption of Black peoples' experiences (hooks, 1992) without the critical engagement necessary to understand structural barriers or to commit to act differently. Moreover, it puts the onus on people of African descent to disclose intimate and sometimes distressful life events, which may retraumatize them. In sum, empathy and awareness are insufficient and do not adequately prepare practitioners to engage in sustainable meaningful transformation-driven actions with African Canadian youth. In order to discover ways to innovate with Black children and youth, this plenary built on the agency and strengths of African Canadian communities, with an Africentric worldview and critical theories.

\section{Africentric Praxis as Politicized Child and Youth Care Praxis}

This presentation from Dr. Julian Hasford, Travonne Edwards, Peter Amponsah, and Juanita Stephen provided an insightful and multilayered analysis of what constitutes anti-racist and Africentric praxis. Drawing from child and youth care literature, the audience was encouraged to decentre the "canonical self" - "an aggregate of the writings of a small group of CYC theorists that together constitute the dominant conceptualization of the self in the field's literature" (Kouri, 2015, p. 601). Kouri (2015) suggested that, as Canada becomes increasingly diverse, we should build upon the concept of "praxis", an ethical way of knowing, doing, and being that involves the integration of theory and practice (White, 2007). Kouri further suggested that child and youth care should strive to move towards politicized praxis to address the barriers that inhibit the well-being and development of the youth we aim to support. Critical theories can show us how to embrace a politicized and collective approach in child and youth care (de Finney et al., 2012; Loiselle et al., 
International Journal of Child, Youth and Family Studies (2020) 11(2): 25-39

2012) as well as how we can learn to name racism and decentre Eurocentric hegemony and worldviews (Yoon, 2012). This includes the widely shared assumption that human services practices and spaces are "universal" and respond to all children's needs equally (de Finney et al., 2011). Principles, practices, and initiatives characterized as universal, and typically derived from Eurocentric philosophies (Saraceno, 2012; Yoon, 2012), are often perceived as the only legitimate or possible guides to professional conduct. Yet a politicized approach to child and youth care requires that we examine critically how colonialism and racism have legitimized a Eurocentric worldview and that we realize that other worldviews conceive of, organize, and define healing differently. This plenary posited that to work effectively with youth of African descent, it is important to espouse an Africentric praxis, which is rooted in African ontology, epistemology, and axiology.

\section{Black-Affirming Spaces and Racial Safety}

The third presentation, from Dr. Beverly-Jean Daniel, emphasized that spaces of racial safety and belonging are central for the holistic and positive development of African Canadian youth. Black-affirming spaces for African Canadians have been discussed in the field of education (Codjoe, 2006; Finlayson, 2015; Henry, 2017; Howard \& James, 2019), yet Black-affirming spaces are less known and implemented in child and youth care. The next section will present the theoretical basis, the inputs, and potential outcomes of Black-affirming spaces.

\section{Beverly-Jean Daniel}

Black children, youth, and families are disproportionately impacted by child welfare and social services involvement. For example, they experience higher numbers of calls made by school authorities to the police to report presumed parental neglect and abuse, higher levels of removal from families and placement in residential and foster care, and higher levels of crossover from the child welfare system into the justice system (Trent et al., 2019). Black youth are also disproportionately represented in behavioural disciplinary programs in school systems (Agyepong, 2010; Baldridge et al., 2011; Codjoe, 2001; James, 2012; James \& Turner, 2017). These patterns of intrusion into Black communities are caused by the intersections of race, class, and historic and contemporary anti-Black oppressive practices. Racism, discrimination, and oppression have negative impacts on children's emotional and psychological development, self-esteem, and sense of personal efficacy (Huguley et al., 2019), and their ability to trust adults and to self-regulate (Bath, 2008). Trent and colleagues (2019) cited the World Health Organization's statement that social determinants of health are shaped by economic, political, and social factors; inequality among these factors, if unaddressed, leads to health inequities. The authors suggested that racism is a social determinant of health, as it has been linked to lower birth weights and higher infant mortality rates; as well, extended exposure to racism-induced stress has negative impacts on hormonal and cellular development. Trent et al. (2019) argued that racism affects where children live and learn, the supports and opportunities they have access to, and the assumptions and stereotypes that are imposed upon them and that inform how they are treated, including their access 
to health care and educational attainment. Therefore, if we were to explore the idea of racism as trauma, we could find opportunities to implement a trauma-informed perspective in supporting Black children and youth.

From a child and youth care perspective, the issue of racism needs to be examined as an aspect or form of trauma. Van der Kolk (2005) defined complex trauma as "the experience of multiple, chronic and prolonged, developmentally adverse traumatic events, most often of an interpersonal nature ... and early life onset" (p. 402). Racism, according to Bryant-Davis and Ocampo (2005) is a form of complex trauma: it involves repeated microaggressions, it can be intense, and the experience is informed by the relationship to the person who perpetrated the harassment. Racism, unlike childhood trauma, is experienced across the lifespan and has been linked to a host of issues related to health and wellness. Bath (2008) indicated that many of the children and youth who are involved in child welfare and special education classes have experienced early-onset trauma. According to Paradies (2006), who reviewed 138 studies related to self-reported racism and stress, there are links between maternal experience of racism and low birth weight, and experiences of racism were directly related to negative mental health outcomes.

Child and youth care practitioners encounter children after there has already been some level of child welfare involvement, making it difficult to determine to what extent mental health challenges were present prior to child welfare involvement, were a result of their involvement, or were exacerbated by their involvement. Ko et al. (2008) further stated that children who are placed in foster and residential care display increased levels of trauma-related stress and behavioural and emotional challenges when placed in care. Therefore, adopting a trauma-informed lens can highlight the role that historical, contemporary, and complex experiences of trauma play in the lives of marginalized communities.

Child and youth care literature on trauma-informed practice identifies three foundational pillars: the promotion of safety, developing positive connections and relationships, and developing the capacity to manage emotions (Bath, 2008). Child and youth care literature that focuses on effective ways for individuals to cope with racism identifies the importance of effective racial socialization and positive support networks (Collin-Vézina et al., 2011). The literature shows similarities in terms of how the impact of trauma and the impact of racism as trauma can be understood; employing an overlapping lens may lead to a more comprehensive form of intervention that recognizes the role of racism in the experiences of Black children and youth.

Neblett et al. (2009) indicated that ethnic-racial socialization provides the framework within which children learn about and make sense of their racial identity and racial group membership and influences the way in which they manage intergroup and intragroup interactions and navigate racialized environments. The researchers indicated that there are four aspects of ethnic-racial socialization: pride and heritage socialization (customs, history, and heritage), bias socialization (teaching children how to anticipate and deal with discrimination), promotion of mistrust (the need for racialized children to be cautious of other groups), and egalitarianism (push towards cultural 
assimilation, which is regarded as a rejection of one's home culture). They found that exposing children and youth to their history and culture through community-based or family gatherings provided them with a foundation for developing a more holistic perspective on and understanding of their lives. A comprehensive discussion of the history of Africans on a global scale provided the children with the information they needed to challenge the stereotypes they were exposed to in all aspects of their world. Bias socialization provided an opportunity for children and youth to discuss and develop strategies for dealing with situations in which they experienced racism while simultaneously teaching them to be aware of the behaviour of other groups.

Huguley et al.'s (2019) summary of findings on the varying forms of socialization indicated that pride and heritage socialization "has consistently been associated with prosocial outcomes" (p. 439). Through these socialization processes, children gradually acquire the prevailing ideas and beliefs about their own racial group and those of others. Research further indicates that parents play a central role in the socialization process (Anglin \& Wade, 2007; Evans et al., 2012); however, family socioeconomic status mediates the form and context of the socialization. Middle-class parents are able to expose their children to a range of situations and contexts that provide positive messages about their racial identity, history, and the forms of resilience displayed by Black people (Sullivan \& Esmail, 2012; Tang et al., 2016). In so doing, parents increase the level of cultural, social, economic, and educational capital their children can access, which can support the development of resilience (Masten et al., 2008). This exposure can be regarded as an aspect of safety: the children and youth are supported in exploring and developing positive relationships with the adults in their world, which is a significant factor in reducing the impacts of racism. Middle-class status provides an additional buffer that may not be available to those Black youth who are living in socioeconomically compromised environments. Often, it is children in lowerincome environments who are most impacted by the reality of class and race-based intersectionality and who are overrepresented in terms of involvement with child welfare services (Ko et al., 2008).

Another aspect of trauma-informed practice is relationship building (Bath, 2008). According to Bath, relationships formed between the child and youth care practitioners and the children and youth they work with can create a model for other healthy relationships and teach the children how to trust adults. Similarly, research has shown that relationships are central to reducing the stressrelated impact of racism: some Blacks actively seek social support to talk about and challenge racism, which can lead to developing greater self-esteem (Paradies, 2006). Codjoe (2006), in his summation of the extant literature, argued that there are three types of primary protective factor that foster academic achievement for racially minoritized students: individual factors, such as temperament and self-esteem; familial factors, such as socioeconomic status and parental academic expectations; and social support, including quality of early schooling and the school environment. His research identified another salient feature of Black academic success - a supportive environment that reinforces racial pride; this replicates the issues of safety and connections identified in trauma-informed practice. It is in the context of these spaces that youth 
are provided with the opportunity to discuss issues of racism and to develop differential analytical framings, which can help them make sense of racism at multiple levels and develop strategies for addressing it. These strategies can address racism at the macro and meso levels, but also at the micro, or individual, level. The micro-level interventions or adaptations align well with the concept of managing emotions identified in trauma-informed practice. Codjoe's work highlights the importance for racially minoritized youth of having access to racially affirming spaces at the same time as they are carving out a role and space for themselves in Canadian society. The ability to navigate multiple cultural environments in this way has been termed biculturality.

Similarly, Daniel-Tatum (1997), in her book Why Are All the Black Kids Sitting Together in the Cafeteria?, indicated that the saliency of race in society leads Black adolescents, as part of their identity development process, to begin to explore the meaning of their racial identity. According to Daniel-Tatum, the students tended to "self-segregate" (1997, p. 217) as a form of protection from racism, and to get support when they experienced racism or were trying to make sense of racist incidents. In addition, the peer group provides opportunities for them to learn racialized performances of Blackness that do not replicate the markers of Blackness of their parents and older family members. Daniel-Tatum did not minimize the important role that parents and family members play; rather, her work highlights the need youth have to be part of peer-based groups that can address the shifting meanings and performances of race in a given time period.

Harris and Krueger (2019) indicated that the existing research shows linkages between positive ethnic or racial identity and academic success:

Promisingly, African American males who do have positive thoughts and feelings about their racial-ethnic identity may enjoy a range of positive outcomes, particularly in the school context. African American youth who feel good about their racial-ethnic background have higher grades, better peer and teacher relationships, and better longterm academic outcomes (such as attending a 4-year college) than peers who harbor negative feelings about their racial-ethnic identity. (p. 2)

Although works by Codjoe (2006), Daniel-Tatum (1997), and Harris and Krueger (2019) focus on the adolescent period of racial identity development and exploration and its relationship to academic success, they make evident that, in the absence of formally constituted spaces of racial safety, Black youth develop strategies for creating safety and connections, and learn strategies for regulating emotions. Paradies (2006) examination of 138 studies concerning self-reported racism and health across all age groups found that the studies clearly highlight the importance of spaces of safety: they are central to positive racial socialization, enhance the academic performance of Black children, and have a positive impact on mental health and well-being. Paradies' analysis of the studies indicated that:

Having a strong sense of racial/ethnic identity or concept ... [and] religious support seeking/instrumental social support ... were found to attenuate the adverse effects 
International Journal of Child, Youth and Family Studies (2020) 11(2): 25-39

of self-reported racism on depressive episodes ... Other research suggests that racial socialization (i.e. explicit discussion of race/racism) imparted by parents or caregivers, but not personal beliefs about racial socialization, may attenuate the detrimental effects of self-reported racism on mental health. (p. 893)

Providing a space for Black children and youth to understand and examine the impact of racism is in alignment with the three pillars of trauma-informed practice — safety, connection, and managing emotions (Bath, 2008).

\section{Racism, Trauma, and Child and Youth Care}

A key question that emerges at this juncture is, "Given that Black children are disproportionately removed from their families and communities, to what extent do we have to explore other sites of racial socialization?" Hughes (2003) defines racial socialization as "the transmission of parents' world views about race and ethnicity to children by way of subtle, overt, deliberate and unintended mechanisms" (Hughes, 2003, p. 15). I would like to extend this definition of racial socialization to include forms and sites of positive racial identity programming and supports that facilitate the exploration, critical negotiation, and navigation of race-related concepts that lead to the development of a positive sense of racial identity and self-concept. Given that child and youth care practitioners often encounter Black children and youth when they are not in the direct care of their parents or community members, these spaces of safety can be developed in schools, community, and residential settings. Daniel (2018) used the term "racial oasis" to describe the spaces that provide options for racial socialization developing positive racial identity markers and a sense of community amongst Black children and youth and which Jean-Pierre, above, refers to as Black-affirming spaces. The role of the family as a central point of racial socialization has been well documented in American research (Constantine \& Blackmon, 2002; Wang et al., 2019; Wang \& Huguley, 2012). However, expanding the notion of safety and potential sites of racial socialization reaffirms the importance of positive racial identifications, and of spaces where Black youth can develop these messages separate and aside from the family. The goal of non-parent-based racial socialization is to support the development of cultural and racial pride, while preparing youth to understand and navigate the racial challenges they will experience. The intentional development of racially affirming spaces can promote the development of positive racial identity amongst Black youth, while supporting them in addressing the multiple sites of trauma and crisis they are attempting to manage.

Black children, youth, and families are exposed to a plethora of negative messages via the media and other forms of social discourse, including schools. Given the fact that these youth spend significant amounts of time engaging in environments away from their families, it is important to examine the impact of providing racially affirming spaces in community and school contexts, particularly given the importance of academic success to social mobility.

VanderVen (1993) indicated that theoretical and applied aspects of the field need to be integrated in order to provide the best quality of services to children and youth who are being 
supported; such integration can provide opportunities for testing theories, furnish training models, and build new theory. Daniel's (2018) research on the importance of reconceptualizing narratives of Blackness provides an example of the theory-practice linkages that are central to the further development of the field of child and youth care and to addressing the needs of Black children, youth, and their families. Daniel's research, which is foregrounded within anti-oppressive and critical anti-racist theories, examined the outcomes for students (high school and post-secondary) who were involved in a series of workshops that focused on positive racial identity development and academic guidance. When their pre- and post-intervention responses were compared, students in the program showed higher levels of positive racial regard, higher levels of self-esteem, and higher awareness of career and academic goals and outcomes. In addition to this, the participants clearly identified the need for spaces that affirmed their racial identities (safety); these provided them with opportunities to meet with other students who had similar experiences (connections); and to discuss strategies to address incidents of racism (managing emotions). Ko et al. (2008) spoke to the importance of evidence-informed practice as central to the development of effective trauma-informed practices.

VanderVen (1993) recognized the resistance that many in the field have to the academic research orientation of other fields and the centrality of in-the-moment relationship-building - a core tenet and practice of the field of child and youth care - to the identity of the field and its practitioners. However, VanderVen argued that reflection in action accompanied by scientific inquiry will provide a more solid foundation for the field. Harris and Krueger (2019) argued for the need to conduct research on the prosocial outcomes of Black male youth, and for a strengthsbased focus in research conducted with Black youth and communities. Strengths-based and ecological frameworks are central aspects of child and youth care theory and politicized practice. They can be pivotal to creating alternative experiences for Black children and youth, and can facilitate a framing of those experiences that is connected to their specific racialized contexts. 
International Journal of Child, Youth and Family Studies (2020) 11(2): 25-39

\section{References}

Agyepong, R. (2010). Black focused schools in Toronto: What do African-Canadian parents say? (Doctoral dissertation). University of Toronto. Retrieved from https://space.library.utoronto.ca/handle/1807/26345

Anglin, D. M., \& Wade, J. C. (2007). Racial socialization, racial identity and Black students adjustment to college. Cultural Diversity and Ethnic Minority Psychology, 13(3), 207-215. doi:10.1037/1099-9809.13.3.207

Baldridge, B. J., Hill. M. L., \& Davis, J. E. (2011). New possibilities: (Re)Engaging Black male youth within community-based educational spaces. Race, Ethnicity and Education, 14(1), 121-136. doi:10.1080/13613324.2011.531984

Bath, H. (2008). The three pillars of trauma-informed care. Reclaiming Children and Youth, 17(3), 18-21.

Bellefeuille, G., McGrath, J., \& Jamieson, D. (2008). A pedagogical response to a changing world: Towards a globally-informed pedagogy for child and youth care education and practice. Children and Youth Services Review, 30(7), 717-726.

doi:10.1016/j.childyouth.2007.11.013

Bernard, W. T., \& Smith, H. (2018). Injustice, justice, and Africentric practice in Canada. Canadian Social Work Review, 35(1), 147-155. doi:10.7202/1051108ar

Briggs, A. Q. (2018). Second generation Caribbean Black male youth discuss obstacles to educational and employment opportunities: A critical race counter-narrative analysis. Journal of Youth Studies, 21(4), 535-551. doi:10.1080/13676261.2017.1394997

Bryant-Davis, T., \& Ocampo, C. (2005). The trauma of racism: Implications for counseling, research, and education. The Counseling Psychologist, 35(4), 574-578. doi:10.1177/0011000005276581

Bundy, J. T. (2019). We'll deal with it later: African Nova Scotian women's perceptions and experiences of the police. Canadian Journal of Sociology/Cahiers canadiens de sociologie, 44(4), 319-342. doi:10.29173/cjs29473

Codjoe, H. M. (2001). Fighting a 'public enemy' of Black academic achievement — the persistence of racism in the schooling experiences of Black students in Canada. Race, Ethnicity and Education, 4(4), 343-375. doi:10.1080/13613320120096652

Codjoe, H. M. (2006). The role of an affirmed black cultural identity and heritage in the academic achievement of African Canadian students. Intercultural Education, 17(1), 33-54. doi: $\underline{10.1080 / 14675980500502271}$ 
International Journal of Child, Youth and Family Studies (2020) 11(2): 25-39

Collin-Vézina, D., Coleman, K., Milne, L., Sell, J., \& Daigneault, I. (2011). Trauma experiences, maltreatment-related impairments, and resilience among child welfare youth in residential care. International Journal of Mental Health and Addiction, 9(5), 577-589.

doi:10.1007/s11469-011-9323-8

Collins, T., \& Magnan, M.-O. (2018). Post-secondary pathways among second-generation immigrant youth of Haitian origin in Quebec. Canadian Journal of Education, 41(2), 413440.

Constantine, M. G., \& Blackmon, S. M. (2002). Black adolescents' racial socialization experiences: Their relations to home, school, and peer self-esteem. Journal of Black Studies, 32, 322-335. doi:10.1177/002193470203200303

Creese, G. (2010). Erasing English language competency: African immigrants in Vancouver, Canada. Journal of International Migration and Integration, 11(3), 295-313. doi:10.1007/s12134-010-0139-3

Daniel, B.-J. M. (2018). The Bridge program: Recasting Blackness, fostering resilience and transformative resistance through narratives of success. Journal of Citizenship Education, $6(1), 1-21$.

Daniel-Tatum, B. (1997). "Why are all the Black kids sitting together in the cafeteria?": And other conversations about race. Basic Books.

de Finney, S., Cole Little, J. N., Skott-Myhre, H., \& Gharabaghi, K. (2012). Roundtable:

Conversations on conversing in child and youth care. International Journal of Child, Youth and Family Studies, 3(2-3), 128-145. doi:10.18357/ijcyfs32-3201210862

de Finney, S., Dean, M., Loiselle, E., \& Saraceno, J. (2011). All children are equal, but some are more equal than others: Minoritization, structural inequities, and social justice praxis in residential care. International Journal of Child, Youth and Family Studies, 2(3-4), 361-384. doi:10.18357/ijcyfs23/420117756

Evans, A. B., Bannerjee, M., Meyer, R., Aldana, A., Foust, M., \& Rowley, S. (2012). Racial socialization as a mechanism for positive development among African American youth. Child Development Perspectives, 6(3), 251-257. doi:10.1111/j.1750-8606.2011.00226.x

Finlayson, M. (2015). Cultural sustainability of African Canadian heritage: Engaging students in learning, the past, the present and the future. Improving Schools, 18(2), 142-156. doi:10.1177/1365480215575350

Harris, J., \& Krueger, A. C. (2019). Exploring the influence of racial-ethnic and gender identity on the prosocial behaviors of African American adolescent males. Youth \& Society (Online First), July, 1-24. doi:10.1177/0044118X19854936 
International Journal of Child, Youth and Family Studies (2020) 11(2): 25-39

Henry, A. (2017). Culturally relevant pedagogies: Possibilities and challenges for African Canadian Children. Teacher's College Record, 119(1), 1-27.

hooks, b. (1992). Black looks: Race and representation. South End.

Howard, P. S. S., \& James, C. E. (2019). When dreans take flight: How teachers imagine and implement an environment that nurtures Blackness at an Africentric school in Toronto, Ontario. Curriculum Inquiry, 49(3), 313-337. doi:10.1080/03626784.2019.1614879

Hughes, D. (2003). Correlates of African American and Latino parents' messages to children about ethnicity and race: A comparative study of racial socialization. American Journal of Community Psychology, 31(1/2), 15-33. doi:10.1023/A:1023066418688

Huguley, J. P.; Wang, M; Vasquez, A. C., \& Guo, J. (2019). Parental ethnic-racial socialization practices and the construction of children of color's ethnic-racial identity: A research synthesis and meta-analysis. Psychological Bulletin, 145(5), 437-458. doi: $10.1037 /$ bul0000187

James, C. E. (2012). Students "at risk": Stereotypes and the schooling of Black boys. Urban Education, 47(2), 464-494. doi:10.1177/0042085911429084

James, C. E. (2019). Adapting, disrupting, and resisting: How middle school Black males position themselves in response to racialization in school. Canadian Journal of Sociology/Cahiers canadiens de sociologie, 44(4), 373-398. doi:10.29173/cjs29518

James, C., David, E., Bernard, W. T., Benjamin, A., Lloyd, B., \& Turner, T. (2010). Race and well-being: The lives, hopes, and activism of African Canadians. Fernwood.

James, C. E., \& Turner, T. (2017). Towards race equity in education: The schooling of black students in the Greater Toronto Area. York University.

Kanu, Y. (2008). Educational needs and barriers for African refugee students in Manitoba. Canadian Journal of Education, 31(4), 915-940. doi: 10.2307/20466734

Ko, S. J., Ford, J. D., Kassam-Adams, N., Berkowitz, S. K., Wilson, C., Wong, M., Brymer, M. J., \& Layne, C. M. (2008). Creating trauma-informed systems: Child welfare, education, first responders, health care, juvenile justice. Professional Psychology: Research and Practice, 39(4), 396-404. doi:10.1037/0735-7028.39.4.396

Kouri, S. (2015). The canonical self and politicized praxis: A tracing of two concepts. International Journal of Child, Youth and Family Studies, 6(4), 595-621. $\underline{\text { doi:10.18357/ijcyfs.64201514290 }}$

Krueger, M. (2007). Four areas of support for child and youth care workers. Families in Society: The Journal of Contemporary Social Services, 88(2), 233-240. doi:10.1606/1044-3894.3621 
International Journal of Child, Youth and Family Studies (2020) 11(2): 25-39

Lafortune, G. (2019). Les jeunes d'origine haïtienne au Cégep: un rapport aux études marqué par le genre [Young people of Haitian origin at Cégep: A gendered relationship to studies]? Canadian Journal of Sociolgy/Cahiers canadiens de sociologie, 44(4), 343-372. doi: $10.29173 / \operatorname{cjs} 29492$

Loiselle, E., de Finney, S., Khanna, N., \& Corcoran, R. (2012). "We need to talk about it!": Doing CYC as politicized praxis. Child and Youth Services, 33(3-4), 178-205. doi:10.1080/0145935X.2012.745778

Maier, H. W. (1991). An exploration of the substance of child and youth care practice. Child and Youth Care Forum, 20(6), 393-411. doi:10.1007/BF00757498

Mann-Feder, V. R., \& Litner, B. (2004). A normative re-educative approach to youthwork education: Department of Applied Human Sciences, Concordia University. Child and Youth Care Forum, 33(4), 275-286. doi:10.1023/B:CCAR.0000035377.36618.d9

Masten, A. S., Herbers, J. E., Cutuli, J. J., \& Lafavor, T. L. (2008). Promoting competence and resilience in the school context. Professional School Counseling, 12(2), 76-84. doi:10.1177/2156759X0801200213

Neblett, E. W., Smalls, C. P., Ford, K. R., Nguyen, H. X., \& Sellers, R. M. (2009). Racial socialization and racial identity: African Amerian parents' messages about race as precursors to identity. Journal of Youth and Adolescence, 38, 189-203. doi:10.1007/s10964-008-9359-7

Ontario Human Rights Commission. (2018). Interrupted childhoods: Over-representation of Indigenous and Black children in Ontario child welfare [Report]. Retrieved from http://www.ohrc.on.ca/sites/default/files/Interrupted childhoods_Over-representation of $\underline{\text { Indigenous and Black children in Ontario child welfare accessible.pdf }}$

Paradies, Y. (2006). A systematic review of empirical research on self-reported racism and health. International Journal of Epidemiology, 35(4), 888-901. doi:10.1093/ije/dy1056

Pon, G., Gosine, K., \& Phillips, D. (2011). Immediate response: Addressing anti-Native and antiBlack racism in child welfare. International Journal of Child, Youth and Family Studies, 2(34), 385-409. doi:10.18357/ijcyfs23/420117763

Robson, K., Anisef, P., Brown, R. S., \& George, R. C. (2018). Under-represented students and the transition to post-secondary education: Comparing two Toronto cohorts. Canadian Journal of Higher Education, 48(1), 39-59. doi:10.7202/1050841ar

Saraceno, J. (2012). Mapping whiteness and coloniality in the human service field: Possibilities for a praxis of social justice in child and youth care. International Journal of Child, Youth and Family Studies, 3(2-3), 248-271. doi:10.18357/ijcyfs32-3201210869 
International Journal of Child, Youth and Family Studies (2020) 11(2): 25-39

Schroeter, S., \& James, C. (2015). "We're here because we're Black": The schooling experiences of French-speaking African Canadian students with refugee backgrounds. Race, Ethnicity and Education, 18(1), 20-39. doi:10.1080/13613324.2014.885419

Sullivan, J. M., \& Esmail, A. M. (2012). African American identity : Racial and cultural dimensions of the Black experience. Lexington.

Tang, S., McLoyd, V. C., \& Hallman, S. K. (2016). Racial socialization, racial identity, and academic attitudes among African American adolescents: Examining the moderating influence of parent-adolescent communication. Journal of Youth and Adolesence, 45, 11411155. doi:10.1007/s10964-015-0351-8

Thésée, G., \& Carr, P. R. (2014). La (re)lecture des mots, du monde et des maux des jeunes noirs : apports de la pédagogie critique à la recherche en éducation en contextes de racialisation [The (re)reading of the words, the world and the woes of young Blacks: Contributions of critical pedagogy to research in education in contexts of racialization]. Canadian Journal of Education/Revue canadienne de l'éducation, 37(1), 308-329.

Trent, M., Dooley, D. G., \& Dougé, J. (2019). The impact of racism on child and adolescent health. Pediatrics, 144(2), 1-14. doi:10.1542/peds.2019-1765

United Nations General Assembly. (2017). Report of the working group of experts on people of African descent on its mission to Canada. Human Rights Council. Retrieved from https://ansa.novascotia.ca/sites/default/files/files/report-of-the-working-group-of-experts-onpeople-of-african-descent-on-its-mission-to-canada.pdf

Usman, L. M. (2012). Communication disorders and the inclusion of newcomer African refugees in rural primary schools in British Columbia, Canada. International Journal of Progressive Education, 8(2), 102-121.

van der Kolk, B. A., (2005). Developmental trauma disorder: Toward a rational diagnosis for children with complex trauma histories. Psychiatric Annals, 35(5), 401-408.

VanderVen, K. (1993). Advancing child and youth care: A model for integrating theory and practice through connecting education, training, and the service system. Child and Youth Care Forum, 22(4), 263-284. doi:10.1007/BF00756952

Yoon, J.-S. (2012). Courageous conversations in child and youth care: Nothing lost in the telling. International Journal of Child, Youth and Family Studies, 3(2-3), 164-186. doi:10.18357/ijcyfs32-3201210864 
International Journal of Child, Youth and Family Studies (2020) 11(2): 25-39

Wang, M.-T., Henry, D. A., Smith, L. V., Huguley, J. P., \& Guo, J. (2019, May 6). Parental ethnic-racial socialization practices and children of color's psychosocial and behavioral adjustment: A systematic review and meta-analysis. American Psychologist. Advance online publication. doi:10.1037/amp0000464

Wang, M.-T., \& Huguley, J. P (2012). Parental racial socialization as a moderator of the effects of racial discrimination on educational success among African American adolescents. Child Development, 83(5), 1716-1731. doi:10.1111/j.1467-8624.2012.01808.x

White, J. (2007). Knowing, doing and being in context: A praxis-oriented approach to child and youth care. Child and Youth Care Forum, 36(5-6), 225-244. doi:10.1007/s10566-007-9043-1

Wortley, S., \& Owusu-Bempah, A. (2011). The usual suspects: Police stop and search practices in Canada. Policing and Society: An International Journal of Research and Policy, 21(4), 395-407. doi:10.1080/10439463.2011.610198 